\title{
A modelling assessment of the maize crop growth, yield and soil water dynamics in the Northeast of Brazil
}

\author{
Marshall Victor Chagas Santos* ${ }^{1}$, André Luiz de Carvalho ${ }^{2}$, José Leonaldo de Souza ${ }^{2}$, Mauricio Bruno \\ Prado da Silva ${ }^{3}$, Rui Palmeira Medeiros ${ }^{2}$, Ricardo Araújo Ferreira Junior ${ }^{2}$, Gustavo Bastos Lyra ${ }^{4}$, lêdo \\ Teodoro ${ }^{2}$, Guilherme Bastos Lyra', Marco Antonio Maringolo Lemes ${ }^{2}$
}

\author{
${ }^{1}$ Department of Agricultural Engineering, Federal University of Viçosa, Viçosa-MG, Brazil \\ ${ }^{2}$ Department of Agrometeorology, Federal University of Alagoas, Maceió-AL, Brazil \\ ${ }^{3}$ Department of Rural Engineering - São Paulo State University, Botucatu-SP, Brazil \\ ${ }^{4}$ Department of Environmental Sciences, Federal Rural University of Rio de Janeiro, Seropédica-RJ, Brazil
}

*Corresponding author: marshallvictor@hotmail.com

Abstract

\begin{abstract}
The present study aims to evaluate the APSIM-Maize model performance to use it as a decision-making tool to help improve production rates, reduce production costs and assess the potential impacts of climate change on crop yields in the Northeast of Brazil. The crop, soil and weather data used in the simulations were obtained from field experiments carried out in maize crops in 2008 and 2011 in two different edaphoclimatic regions in Alagoas State, Northeast Brazil. The approach we used explored the ability of APSIM to simulate growth variables and soil water dynamics of a maize variety (AL Bandeirante). During parametrization, we made some adjustments regarding the variety and soil organic matter to attain a better representation of the growth and soil water dynamics, respectively. The APSIM-Maize model predicted the leaf area index with a RMSE (Root Mean Square Error) ranging between 0.14 and $1.06 \mathrm{~cm}^{2} \mathrm{~cm}^{-2}$ and the biomass production with an RMSE between 2.30 and $3.34 \mathrm{Mg}$ ha ${ }^{-1}$. The volumetric soil water content was satisfactorily predicted with RMSE ranging between 0.02 and $0.08 \mathrm{~mm} \mathrm{~mm}^{-1}$. Results showed that this model is a useful tool for decision-making, which can be potentially used as a support in climate risk management and policies, aiming to improve regional production, provided it has been previously validated with independent datasets.
\end{abstract}

Key words: Agricultural systems; APSIM; Crop simulation model; Field experiment; Sowing date; Zea Mays L.

Abbreviations: ADD_Accumulated Degree-Day; APSIM_The Agricultural Production System Simulator; DAS_Days After Sowing; DOY_Day Of Year; DUL_Soil Water Content at Drained Upper Limit; k_Canopy Light Extinction Coefficient; LAI_Leaf Area Index; LL_Soil Water Content at Drained Lower Limit; PAR_Photosynthetically Active Radiation; RUE_Radiation Use Efficiency; SW_Soil Water Content; TDR_Time-Domain Reflectometry;

Introduction

Maize has a high socioeconomic value worldwide because its cereal is used to produce food for human and animal consumption. In addition, the grains are also widely used as a renewable energy source (Koizumi, 2015). The global average productivity in 2016 was $5.6 \mathrm{Mg} \mathrm{ha}^{-1}$ according to the Food and Agriculture Organization of the United Nations (FAO). At present, the USA is the largest maize producer in the world and in 2016 it produced $10.6 \mathrm{Mg} \mathrm{ha}^{-1}$ of grain and has an historical average of $7.1 \mathrm{Mg} \mathrm{ha}^{-1}$. Brazil is the third largest maize producer as it produced $5.5 \mathrm{Mg} \mathrm{ha}^{-1}$ of grain in 2016 (FAO, 2018). However, climate and edaphic restrictions (e.g., soil with low fertility or low water retention capacity and salinity), as well as low technological levels and inadequate management practices are factors that contribute to Brazil having a historical average yield of only $2.8 \mathrm{Mg} \mathrm{ha}^{-1}$ (CONAB, 2018).

A huge demand for food due to the increasing global population has jeopardized the sustainability of agriculture and requires higher production levels without increasing planted areas. This requires using crop modelling to estimate the potential productivity of large regions with relatively low levels of productivity. Roxburgh and Rodriguez (2016) reported that the spatial variability of productivity is mainly associated with soil fertility and soil handling techniques (crop density, population and planting season) and a general lack of technical knowledge. In addition, the seasonal variability of productivity can be explained by the variability in rain producing weather systems. It is estimated that putting these factors aside, maize yield could increase by up to $120 \%$. In Northeast Brazil, most of the maize crops are grown in rainfed conditions and are for self-sustaining, showing a historical average productivity of around $0.9 \mathrm{Mg}$ $\mathrm{ha}^{-1}$ (last harvest of 2016-2017 $=2.5 \mathrm{Mg} \mathrm{ha}^{-1}$ ). Productivity in Alagoas is still smaller with a historical average of only 0.5 $\mathrm{Mg} \mathrm{ha}{ }^{-1}$ between 1976 and 2017, which is 82.1 and $44.5 \%$ lower than the national and regional yield, respectively (CONAB, 2018). However, Ferreira Junior et al. (2014) and Lyra et al. (2010) showed that in this region, the yield can be 
increased to about 6.0 to $8.7 \mathrm{Mg} \mathrm{ha}^{-1}$ under experimental conditions based on good management practices.

Process-based mathematical models of plant growth are essential for identifying environmental restrictions, thus allowing higher levels of crop production. Agricultural modelling began in the 1960 s aiming at simulating photosynthetic rates of crops (de Wit, 1965). Since then, the search for better methods to improve the performance of agricultural systems through process-based crop models has been a very active area of research in agriculture (Keating et al., 2003; Carberry et al., 1993; Muchow et al., 1990). The main application of crop modelling is crop management and environmental risk decision making. Nowadays, crop models are also widely used to evaluate the potential consequences of climate change on crop yields (Roberts et al., 2017; Bassu et al., 2014).

The APSIM (Agricultural Production System Simulator) is a modular modelling framework that simulates various interactions among plants, animals, soil, climate and agricultural management (Keating et al., 2003). Studies have shown that APSIM is suitable for many applications in agricultural production systems (Ojeda et al., 2016; Singh et al., 2014; Zeleke et al., 2014; Monhanty et al., 2012). Archontoulis et al. (2014) evaluated the overall performance of APSIM-Maize in the Midwestern United States. They concluded that the model can be used as a research and decision-making tool to provide agricultural support in the Midwest. Song et al. (2010) used APSIM-Maize to evaluate the effects of water stress on maize growth and yield under dryland conditions in southeast Queensland. Results showed that APSIM performed accurately, and therefore the model can be used as a tool to assess maize production with new cultivars in drier and less predictable environmental situations, provided the parametrization of cultivars and soil characteristics are accurate.

The main objective of this paper is to provide an overall assessment of the APSIM model performance in Northeast Brazil, aiming to use it as a tool to help improve regional production. More specifically, our goal is to assess the performance of the APSIM model to simulate growth, biomass, grain yield and soil water dynamics for a maize variety in two regions of Alagoas State, Northeast Brazil.

\section{Results}

\section{Growth variable analyses}

Leaf area index (LAI) measurements (Fig 2) showed the largest amplitudes for Rio Largo (Fig 2e-h) with a maximum value of $5.41 \mathrm{~cm}^{2} \mathrm{~cm}^{-2}$ (Fig 2f) at 57 days after sowing (DAS). The smallest variation of LAl was found in Arapiraca during the fourth sowing date (Fig $2 \mathrm{~d}$ ), with a maximum value of $3.64 \mathrm{~cm}^{2} \mathrm{~cm}^{-2}$ at 65 DAS. The LAl simulations for Arapiraca showed a percentage relative error of $21 \%$ (Fig 2) ranging between 12\% (Fig 2a) and 29\% (Fig 2b). For Rio Largo (Fig 2eh), the model showed an averaged error of $29 \%$. Moreover, the best performance was observed on the fourth sowing date (Fig 2f) with an error of approximately $14.2 \%$.

The model performed very well in estimating LAl for Arapiraca with RMSE of $0.305 \mathrm{~cm}^{2} \mathrm{~cm}^{-2}$ (Fig 2a-d), and $d$ of 98.7\%. In particular, the fourth sowing date (Fig 2d) showed the best agreement $(d=99.7 \%)$ and precision (RMSE $=0.14$ $\mathrm{cm}^{2} \mathrm{~cm}^{-2}$ and $R^{2}=0.96$ ), thus indicating a very good performance of the simulation. For this specific case, the highest performance was achieved after increasing the effective depth of the root system from $60 \mathrm{~cm}$ to $75 \mathrm{~cm}$, which corresponded to a $25 \%$ drop in the simulation error. As the experiment was conducted under rainfed conditions, we considered this modification necessary due to the low water availability in the soil from the end of the vegetative stage in mid-September (DOY 250, Fig 4d), until the harvest at the end of October (DOY 297). The LAl predictions for Rio Largo showed a good agreement $(d)$ of 95.0\% and a reasonable precision $\left(R^{2}=0.63\right)$. In addition, we observed a larger RMSE of $0.68 \mathrm{~cm}^{2} \mathrm{~cm}^{-2}$ when comparing them with the results for Arapiraca. In general, all the LAI simulations were considered very efficient (i.e., $0<\mathrm{EF}<1$ ) as the EF for Arapiraca and Rio Largo were 0.95 and 0.87, respectively. A low EF of -0.15 (i.e., $E F<0$ ) was observed only in one case (second sowing date in Rio Largo), indicating poor efficiency. The low EF, for this specific case, did not invalidate the simulation, however it means that the model predictions were worse than simply using the observed mean to replace the simulated value (Yang et al., 2014a).

The total biomass production obtained from the field experiment was larger in Rio Largo (Fig $3 e-f$ ) ranging from 15.2 $\mathrm{Mg} \mathrm{ha}^{-1}$ (sowing 4 - Fig 3h) to $17.4 \mathrm{Mg} \mathrm{ha}^{-1}$ (sowing 2 Fig 3f). Smaller values were obtained in Arapiraca which ranged from $10.3 \mathrm{Mg} \mathrm{ha}^{-1}$ (sowing 4 - Fig 3d) to $12.26 \mathrm{Mg}$ ha $^{-}$ ${ }^{1}$ (sowing 2 and $3-$ Fig $3 b, c$ ). The grain yield obtained from the field experiment in Arapiraca showed large variations among the sowing dates, i.e. $1.96 \mathrm{Mg} \mathrm{ha}^{-1}$ (sowing 4) and $4.11 \mathrm{Mg} \mathrm{ha}^{-1}$ (sowing 2), which in turn was the largest grain yield considering all sowing dates studied (Fig 3b). For Rio Largo, the grain yield obtained in the field experiment showed smaller values and less variations among the sowing dates, which ranged from $2.20 \mathrm{Mg} \mathrm{ha}^{-1}$ (sowing 4, Fig 3h) to $3.70 \mathrm{Mg} \mathrm{ha}^{-1}$ (sowing 2, Fig 3f). The experimental data shown above revealed that the largest values of total biomass and grain yield were associated with earlier sowing dates. As mentioned previously, both experiments were conducted under rainfed conditions and, therefore, the latest sowing season suffered from the low water availability in the soil between the vegetative period and the harvest due to the annual rainfall pattern in these regions (see Fig. 4). Hence, for the latest sowing date the reduction in rainfall was responsible for the smaller values of biomass and grain yield, mainly for Arapiraca (Fig 3d and Fig 4d).

The model estimated the biomass production for Arapiraca with a RMSE of $3.11 \mathrm{Mg} \mathrm{ha}^{-1}$ and underestimated the observations (above 20\%) for all cases (Fig 3a-d). Despite these high underestimates, a good precision $\left(R^{2}=0.86\right)$ was observed, as well as an agreement index $(d)$ of $83.7 \%$. This highest precision and smaller accuracy indicate that the total error may have contributed to a larger systematic component (Willmott, 1981). The results for the grain yield were also quite satisfactory as the error ranged between $12.9 \%$ (sowing 1 ) and $15.5 \%$ (sowing 3 ), within the accepted error threshold $( \pm 20 \%)$ for the first three sowing dates (Fig $3 a-c)$. The biomass predictions for Rio Largo were more accurate than those for Arapiraca $(d=92.6 \%)$, showing slightly less precision (RMSE $~ 2.31$ to $2.63 \mathrm{Mg} \mathrm{ha}^{-1}$ and $R^{2}=$ 0.82 ). However, the grain yield was overestimated by the model around $42 \%$ for the first three sowing dates (Fig 3e-g). 
Table 1. Sowing and harvest dates regarding the field experiments of Arapiraca (2008) and Rio Largo (2011) in Alagoas, Northeast Brazil.

\begin{tabular}{cllll}
\hline Sowing date & Arapiraca & & Rio Largo & \\
\hline & Sowing & Harvest & Sowing & Harvest \\
\cline { 2 - 5 } Sowing 1 & $14 / 06$ & $01 / 09$ & $06 / 05$ & $12 / 10$ \\
Sowing 2 & $22 / 06$ & $16 / 09$ & $19 / 05$ & $16 / 10$ \\
Sowing 3 & $28 / 06$ & $06 / 10$ & $10 / 06$ & $31 / 10$ \\
Sowing 4 & $05 / 07$ & $24 / 10$ & $30 / 06$ & $04 / 11$ \\
\hline
\end{tabular}

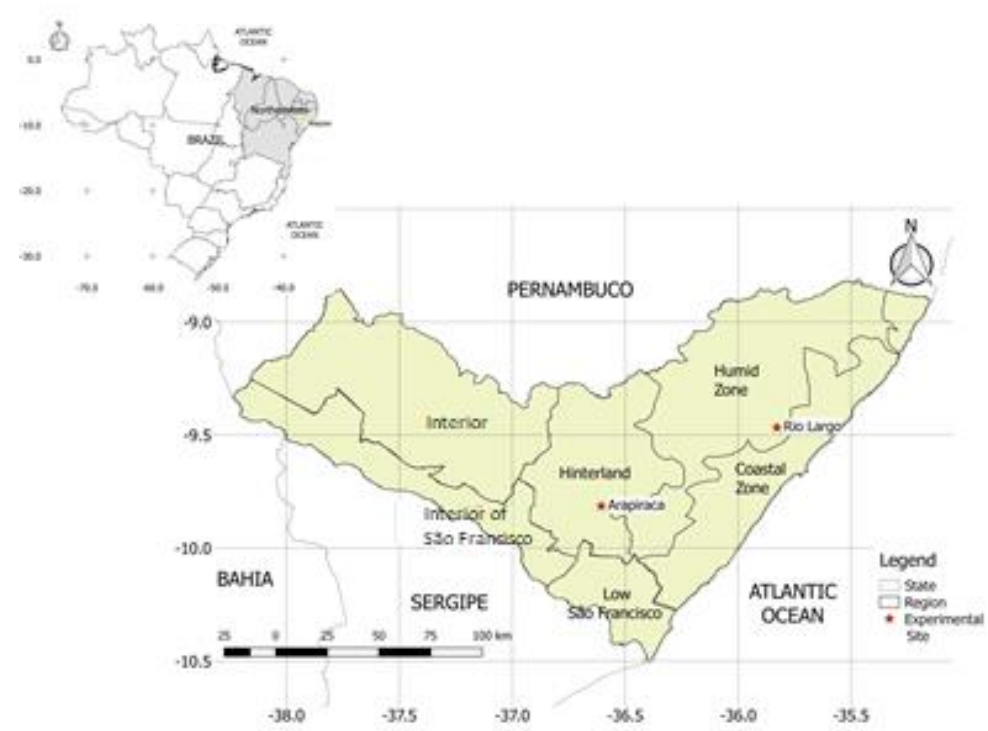

Fig 1. Map of the State of Alagoas in Northeast Brazil, showing the experimental site (red stars) locations.

Table 2. Soil hydrophysical properties: Bulk density (BD), 15Bar lower limit of soil water content (LL15), drained upper limit (DUL) and water content at saturation (SAT) used in APSIM-Maize module for the Arapiraca and Rio Largo simulations.

\begin{tabular}{|c|c|c|c|c|c|}
\hline & Depth & BD & LL15 & DUL & SAT \\
\hline & $\mathrm{cm}$ & $\mathrm{g} \mathrm{cm}^{-3}$ & & $\mathrm{~mm} \mathrm{~mm}^{-1}$ & \\
\hline \multirow{2}{*}{ 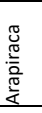 } & $0-30$ & 1.33 & 0.063 & 0.102 & 0.40 \\
\hline & $30-60$ & 1.38 & 0.076 & 0.113 & 0.39 \\
\hline \multirow{3}{*}{$\begin{array}{l}\frac{0}{0} \\
\frac{0}{J} \\
\frac{0}{\sigma}\end{array}$} & $0-10$ & 1.36 & 0.12 & 0.20 & 0.40 \\
\hline & $10-20$ & 1.44 & 0.13 & 0.22 & 0.43 \\
\hline & $20-30$ & 1.52 & 0.14 & 0.24 & 0.43 \\
\hline
\end{tabular}

Leaf area index simulated

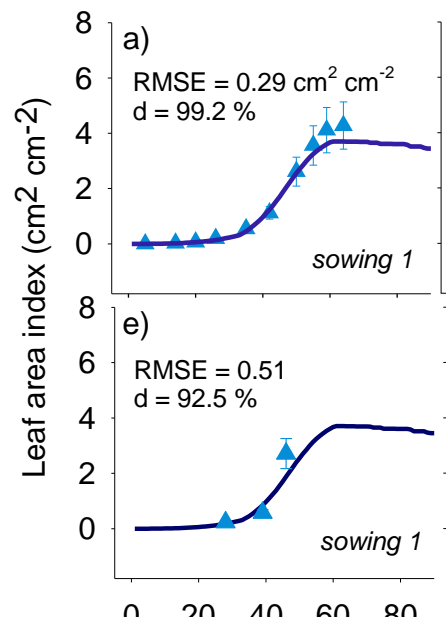

b)
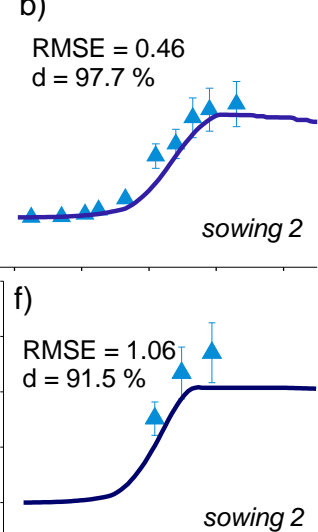

$0 \quad 20 \quad 40 \quad 60 \quad 80$
- Leaf area index observed

c) d)

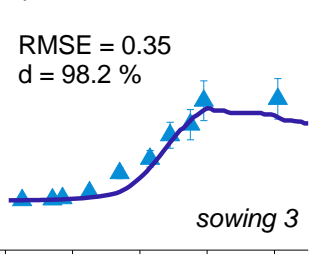

g)

RMSE $=0.71$

$d=97.0 \%$

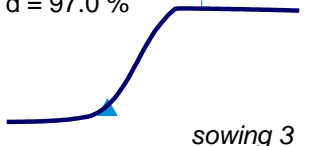

sowing 3

RMSE $=0.14$

$d=99.7 \%$

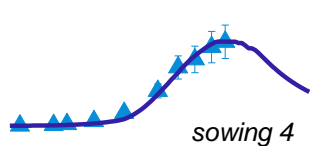

h)

RMSE $=0.46$

$d=98.6 \%$

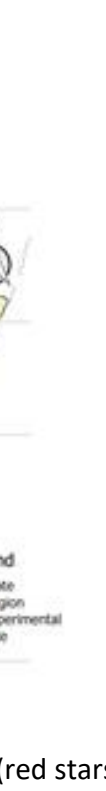

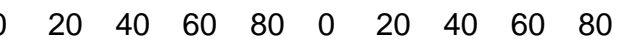

Days after sowing

Fig 2. Measured and simulated leaf area index (LAI) as a function of days after sowing (DAS) for four sowing dates in Arapiraca (Fig 2a-d) and Rio Largo (Fig 2e-h). 
Table 3. Soil chemical properties: water $\mathrm{pH}$-value $(\mathrm{pH})$, starting mineral $\mathrm{N}$ pools $\left(\mathrm{NH}_{4}\right.$ and $\left.\mathrm{NO}_{3}\right)$, organic carbon $(\mathrm{OC})$, biomass fraction (FBIOM) and inert OC fraction (FINERT), used for the Arapiraca and Rio Largo simulations.

\begin{tabular}{|c|c|c|c|c|c|c|c|}
\hline & $\begin{array}{l}\text { Prof. } \\
\mathrm{cm}\end{array}$ & $\begin{array}{l}\mathrm{NH}_{4} \\
\mathrm{mg} \mathrm{kg}^{-1}\end{array}$ & $\begin{array}{l}\mathrm{NO}_{3} \\
\mathrm{mg} \mathrm{kg}^{-1}\end{array}$ & $\begin{array}{l}\text { OC } \\
\% \\
\end{array}$ & $\begin{array}{l}\text { FBIOM } \\
(0-1)\end{array}$ & $\begin{array}{l}\text { FINERT } \\
(0-1)\end{array}$ & $\begin{array}{l}\mathrm{pH} \\
\text { (water) }\end{array}$ \\
\hline \multirow{2}{*}{$\begin{array}{ll}\bar{\alpha} \\
\frac{0}{0} \\
\frac{0}{2}\end{array}$} & $0-30$ & 3.30 & 6.45 & 2.66 & 0.023 & 0.46 & 5.23 \\
\hline & $30-60$ & 0.78 & 0.99 & 0.99 & 0.010 & 0.62 & 4.30 \\
\hline \multirow{3}{*}{ 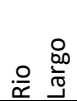 } & $0-10$ & 1.30 & 1.75 & 1.03 & 0.035 & 0.39 & 5.52 \\
\hline & $10-20$ & 1.00 & 2.58 & 0.86 & 0.020 & 0.47 & 5.10 \\
\hline & $20-30$ & 1.00 & 2.12 & 0.77 & 0.015 & 0.52 & 5.00 \\
\hline
\end{tabular}

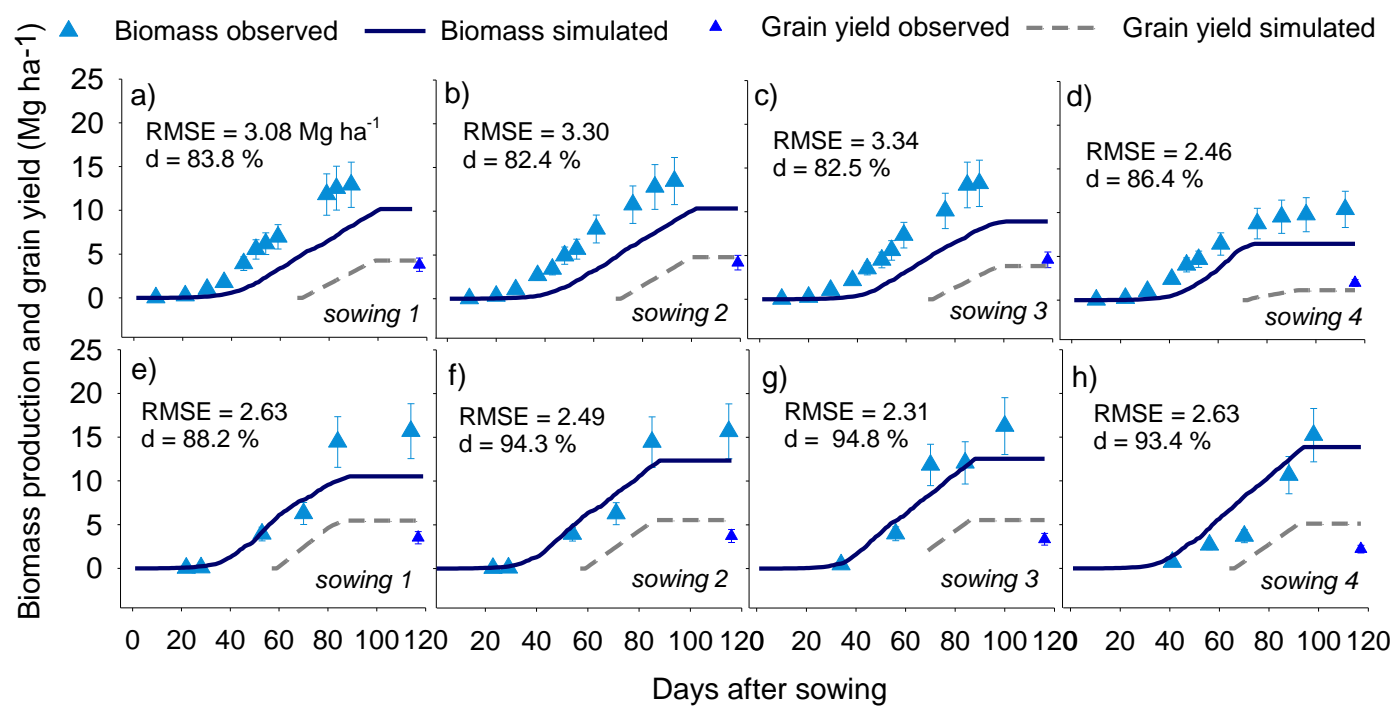

Fig 3. Measured and simulated aboveground biomass and grain yield $\left(\mathrm{Mg} \mathrm{ha}^{-1}\right)$ for four sowing dates in Arapiraca, AL (Fig 3a-d) and Rio Largo, AL (Fig 3e-h). The statistical indices indicated in the panels refer to biomass.

Table 4. Parameters used to adjust the leaf area index (LAI) for the Arapiraca and Rio Largo simulations.

\begin{tabular}{llll}
\hline Parameter & Value APSIM & Value used & Description \\
\hline x_lai & $0.1-4.0$ & $0.1-6.0$ & LAl range \\
leaf_no_dead_slope & 0.00035 & 0.0002 & Slope LAI - associated with leaf age senescence \\
lai_sen_light & 4.0 & 6.0 & Occurrence of induced senescence by light \\
\hline
\end{tabular}

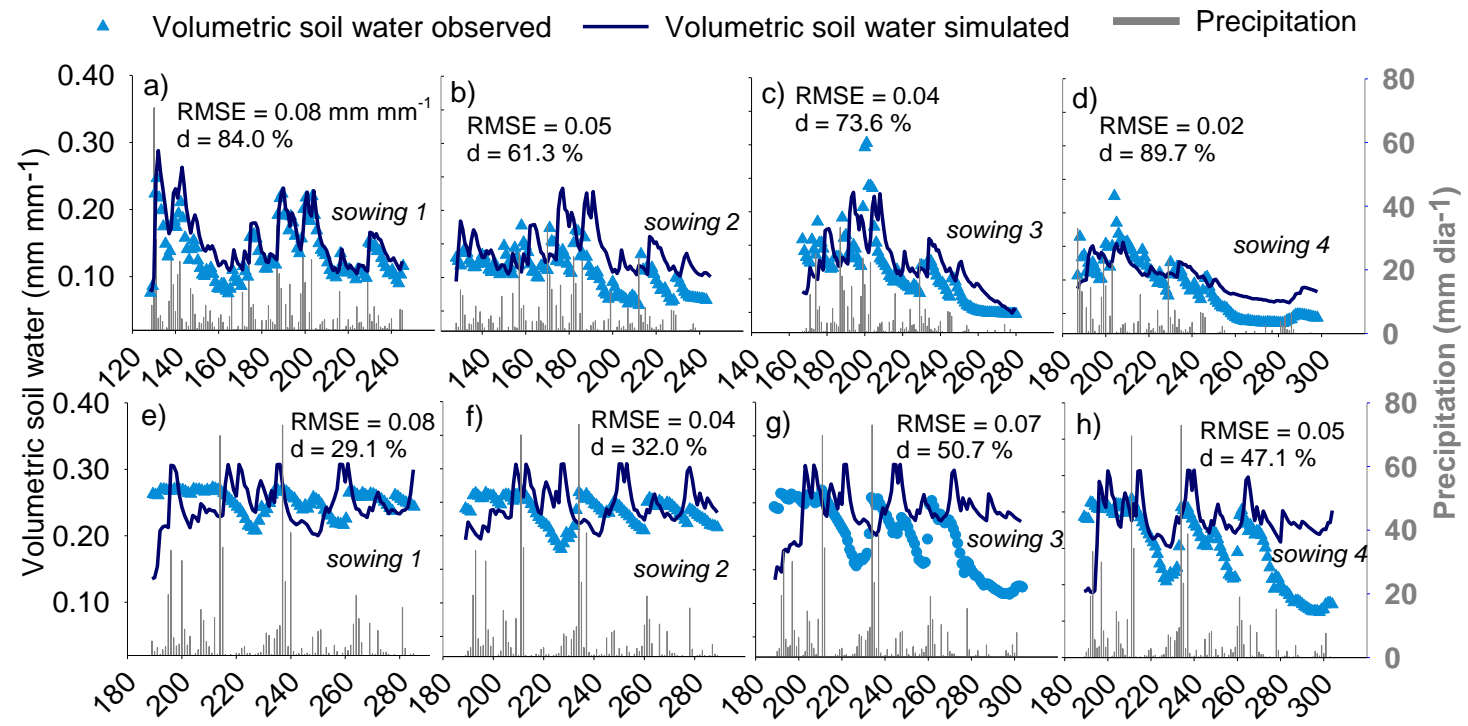

Day of year

Fig 4. Measured and simulated volumetric soil water content $\left(\mathrm{mm} \mathrm{mm}^{-1}\right)$ at the layer $0-60 \mathrm{~cm}$ and daily precipitation for four sowing dates in Arapiraca, AL (Fig 4a-d) and Rio Largo, AL (Fig 4e-h). 
Table 5. Phenological parameters used in the parametrization of maize variety (AL Bandeirante) for the Arapiraca and Rio Largo simulations.

\begin{tabular}{lll}
\hline Parameter & Value & Description \\
\hline tt_emerg_to_endjuv & 196.08 & ADD between the emergency and the end of the juvenile stage. \\
tt_flower_to_maturity ${ }^{2}$ & 1968.1 & ADD between the flowering and maturity. \\
tt_flag_to_flower ${ }^{3}$ & 48.10 & ADD the flag leaf appearance and flowering. \\
tt_flower_to_start_grain ${ }^{4}$ & 68.5 & ADD flowering to grain filling \\
tt_maturity_to_ripe & 1 & ADD between maturity and harvest. \\
ADD between emergence to ${ }^{\text {th }}$ fully expanded leaf (V4); ${ }^{2}$ ADD between flowering (R1) to maturity (R6); ${ }^{3}$ ADD between two days after tasseling (VT) to flowering (R1); ${ }^{4}$ ADD between flowering (R1) \\
to start of the grain filling (R2); ${ }^{5}$ ADD between maturity (R6) to harvest.
\end{tabular}

\section{Soil water dynamics analyses}

The soil moisture observations using a TDR (Time Domain Reflectometer) indicated that for Arapiraca the maximum values of the volumetric soil water content $\left(\mathrm{SW}, \mathrm{mm} \mathrm{mm}^{-1}\right.$ ) ranged between $0.15 \mathrm{~mm} \mathrm{~mm}^{-1}$ (Fig 4d) and $0.24 \mathrm{~mm} \mathrm{~mm}^{-1}$ (Fig 4a) during the growing season considering all sowing dates. These values for Rio Largo were around $0.26 \mathrm{~mm} \mathrm{~mm}^{-}$

${ }^{1}$ (Fig 4e-h). Overall, the model estimated the soil water dynamics with a small error (less than $\pm 20 \%$ ). The Arapiraca simulation for the first and last sowing dates (Fig 4a,d) showed smaller estimation errors, ranging from $14.5 \%$ (sowing 4) to $19.9 \%$ (sowing 1). For Rio Largo, the SW estimates showed an error of the order of $22.1 \%$ (Fig $4 \mathrm{e}-\mathrm{h}$ ). The model simulated the soil water dynamics for Arapiraca (Fig 4a-d) and Rio Largo (Fig 4e-h) with an RMSE of $0.04 \mathrm{~mm}$ $\mathrm{mm}^{-1}$ and $0.06 \mathrm{~mm} \mathrm{~mm}^{-1}$, respectively. The first sowing date for Arapiraca (Fig. 4a) showed that the model satisfactorily reproduced the pattern of measured soil water content (RMSE $=0.08 \mathrm{~mm} \mathrm{~mm}^{-1}$ and $d=84.0 \%$ ), which showed successful soil water parametrization. This parameterization also performed well on the other sowing dates, in which the observations and simulations showed similar trends despite their different magnitudes in some cases. Thus, evidence was shown that the model succeeded in simulating the real process of the soil water dynamics. However, this result is not surprising because the APSIM's soil water module requires soil water content data at the drained upper limit (DUL) and lower limit (LL), both determined from experimental conditions (Archontoulis et al., 2014).

\section{Discussion}

The reasonable performance of LAl estimates in Rio Largo did not affect the accuracy of the estimates of biomass production although LAI is an important variable when calculating the intercepted light and photosynthesis in the model. Asseng et al. (1998) points out that it is surprising that LAl estimates do not seriously affect the biomass predictions. This apparent lack of sensitivity of the estimated LAI on the biomass, in some cases, could be explained by the fact that accurate LAl simulations are more important in early growth stages and during the grain filling period. However, less relevance is observed when the ground is fully covered (maximum LAI), where at that point an increase in LAI has a marginal effect on light interception. This may explain why the biomass production estimates were not adversely affected by relatively poor LAl estimates, although the biomass production was sensitive to modifications made in the LAI parametrization, such as those discussed below. A reliable prediction of LAI is important to obtain good estimates of biomass production. The fitted parameters in calculating LAI were important for a better representation of the growth conditions, resulting in more reliable estimates of biomass production and grain yield. Following the procedure adopted by Archontoulis et al. (2014), the parameter associated with the leaf age senescence (leaf_no_dead_slope) was reduced from 0.00035 to 0.0002 to attain a better representation of the decay of the LAI curve due to leaf senescence. In addition, to better fit the LAl range (x_lai) parameter to the field observations, we expanded the LAI upper limit from 4.0 to 6.0. Note that the maximum LAI in Rio Largo was 5.6 (Fig 2e). In other words, the former upper limit considered in the model was not large enough to meet the LAI variations obtained in the field observations. Overall, the LAl estimates in this study were very satisfactory for Arapiraca, but not as much for Rio Largo, as previously mentioned. A study conducted by Archontoulis et al. (2014) in the Midwestern United States considered that APSIM-Maize predicted LAI satisfactorily with a precision of $21 \%$. However, research carried out in Australia (Asseng et al., 1998; Meinke et al., 1997), using the APSIM-Wheat module, reported quite a poor performance in LAl predictions.

The biomass production (Fig 3 ) is highly dependent on the canopy light extinction coefficient $(k)$, which in turn was maintained as the APSIM's default value. Ferreira Junior et al. (2014) found $k=0.62$ for the AL Bandeirante variety, considering photosynthetically active radiation (PAR). This value corresponds practically to the same value considered in the model $(k=0.53)$, taking into account the proportionality to solar global irradiation $\left(\mathrm{H}_{\mathrm{g}}\right)$. For the radiation use efficiency (RUE), we used APSIM's default values for maize in which RUE is considered as constant (1.6 $\mathrm{g} \mathrm{MJ}^{-1}$ ) until the beginning of the grain filling, then it is reduced to $1.4 \mathrm{~g} \mathrm{MJ}^{-1}$ (Muchow et al., 1990) due to the reduction in the photosynthetic rate stemming from the senescence of the leaves. Recent studies carried out in the USA have reported that RUE for maize is about $1.67 \mathrm{~g} \mathrm{MJ}^{-1}$ $\mathrm{Hg}$, matching with the value used in our simulations (Archontoulis et al., 2014; Singer et al., 2009).

The model did not satisfactorily reproduce the soil water pattern for Rio Largo (Fig 4e-h), even using hydro-physical parameters determined experimentally. This was largely due to the soil type of the region, which has a compacted layer situated around $30 \mathrm{~cm}$ deep and did not properly reproduce by the drainage parameter of the model. It was noticed that the model overestimated the SW immediately after days or periods with large accumulated rainfall. On the other hand, it showed a better performance regarding the SW estimates for low rainfall periods. In other words, the model was able to recognize the compact layer, which reduces the drainage of the soil water, thus underestimating the drainage rates. For this very reason, the soil water conductivity parameter (SWCON, $\mathrm{d}^{-1}$ ) was increased from 0.2 (Probert et al., 1998) to 0.6 , using an iterative method to achieve a better agreement of SW. The SWCON parameter represents the water above DUL which is drained daily. 
Using the APSIM-Maize in central western USA, Archontoulis et al. (2014) reported RMSE of $0.03 \mathrm{~mm} \mathrm{~mm}^{-1}$ for the soil water dynamics simulations. We obtained a similar precision in our results for Arapiraca (Fig 4a-d). A reasonable performance of APSIM in predicting SW was noticed when simulating the cotton crop in northern China (Yang et al., 2014b) with $R^{2}$ ranging from 0.33 and 0.56 . Good precision was found for wheat in western Australia (Aseng et al., 1998) and canola in southern Australia (Zeleke et al., 2014), which reported $R^{2}$ of 0.92 and 0.94 , respectively. Finally, the SW predictions in this study indicate a good efficiency of the APSIM model in calculating soil water dynamics under well drained soils (e.g., soil in Arapiraca) in close agreement with other studies (Aseng et al., 1998; Mohanty et al., 2012).

\section{Materials and Methods}

\section{Experimental data}

This study uses experimental data in rainfed conditions from two edaphoclimatic different regions in Alagoas State, located on the eastern coast of Northeast Brazil (Fig 1): 1) Arapiraca ( $9^{\circ} 48^{\prime} 55.1^{\prime \prime}$ S; 36 $36^{\circ} 22.8^{\prime \prime}$ W; 260 a.s.l.) in 2008 and 2) Rio Largo $\left(09^{\circ} 28^{\prime} 02 " S\right.$; $35^{\circ} 49^{\prime} 43^{\prime \prime} W ; 127 m$ a.s.l.) in 2011. Arapiraca's climate is $\left(A s^{\prime}\right)$, according to the Köppen classification with a dry Summer and rainy Autumn and Winter; temperatures are high throughout the year (annual average air temperature of $25^{\circ} \mathrm{C}$ and precipitation totals between 750 and $1000 \mathrm{~mm}$ year $\left.{ }^{-1}\right)$. The rainiest months are May and June (> $50 \%$ of the annual total). The soil is classified as dystrophic Red Yellow Latosol, with a sandy loam texture and the bulk density is $1.35 \mathrm{~g} \mathrm{~cm}^{-3}$ in the first $60 \mathrm{~cm}$ depth. The experimental design used was a randomized block design with six replicates and four sowing dates by treatment (Table 1). Row spacing was $0.80 \mathrm{~cm}$ and each experimental plot consisted of 12 rows $10 \mathrm{~m}$ long, which resulted in a stand population of 55,000 plants $\mathrm{ha}^{-1}$. Further experimental details for Arapiraca can be found in Medeiros (2009).

The Rio Largo experiment was carried out at the Center of Agricultural Sciences at the Federal University of Alagoas (CECA/UFAL). The climate of the Rio Largo region is classified as As according to the Köppen classification, with monthly average minimum and maximum air temperatures of 17.2 and $35.2^{\circ} \mathrm{C}$, respectively. The interannual rainfall variability is high, with an annual average of $1800 \mathrm{~mm}$. The rainy season starts in early April and lasts until late August, with a total that corresponds to $70 \%$ of the annual total; the dry season spans from early October until the first half of February, representing about $16 \%$ of the total precipitation (Souza et al., 2004). The soil of Rio Largo site is classified as Distrocohesive Yellow Latosol, intermediate/clayey texture with an average density of $1.44 \mathrm{~g} \mathrm{~cm}^{-3}$ in its first $30 \mathrm{~cm}$. The experimental design used was a randomized block design with five replicates and four sowing dates by treatment (Table 1). The experimental field was approximately $960 \mathrm{~m}^{2}$ ( 0.096 ha and the plot dimensions were $8 \times 6 \mathrm{~m})$. Row spacing was $0.80 \mathrm{~m}$, and each experimental plot consisted of 10 rows $6 \mathrm{~m}$ long; the stand population was 75,000 plants $\mathrm{ha}^{-1}$. Further experimental details for Rio Largo can be found in Silva (2013).

For both sites, the depth of the radicular system set up in the model was $0.60 \mathrm{~m}$, according to the field observations. The maize variety used was the AL Bandeirante, which were sown in four different dates during 2008 (Arapiraca's site) and 2011 (Rio Largo's site), as shown in Table 1.

\section{Input datasets}

The weather data were grouped in a metfile, containing daily data such as (i) global solar irradiation ( $\mathrm{MJ} \mathrm{m}^{-2}$ ) obtained using a Pyranometer (CM3, Kipp \& Zonen); (ii) air temperature and humidity $\left({ }^{\circ} \mathrm{C}\right)$ obtained using a thermohygrometer (HMP45C, Vaisala Inc.); (iii) wind speed $\left(\mathrm{m} \mathrm{s}^{-1}\right.$ ) obtained using a cup anemometer (051035/Young, Campbell Sci.); (iv) rainfall ( $\mathrm{mm}$ ), obtained using a pluviometer (TB3, Hydrological Service PTY, Sydney, Australia). All the above data were collected at agrometeorological stations using a datalogger (CR1000, Campbell, Sci. Logan, Utah). The soil water content $\left(\mathrm{mm}^{3} \mathrm{~mm}^{-3}\right)$ measurements utilized to evaluate the simulated soil water dynamics were obtained using a TDR (model-CS616, Campbell Sci. Logan, Utah). The TDR calibration procedures for Arapiraca and Rio Largo can be found in Medeiros (2009) and Sarmento (2015), respectively.

\section{APSIM configuration}

The APSIM version 7.6 was used in this study on a daily time step. The simulations were configured using the following modules: MAIZE (crop module), FERTILIZER and SURFACEOM. The application of fertilizer was programmed using the "operations schedule" function - available in the APSIM's management toolbox - that creates a chronology of all operations.

\section{APSIM parametrization}

The model parametrization was achieved according to an established logical pattern: (i) meteorological and soil variables, representative of the local environmental conditions, were inserted; (ii) phenological parameters of the maize variety were used to perform the crop parametrization; (iii) finally, an interactive approach was used to fit some variables such as soil water content, LAI and biomass. During the parametrization, several sensitivity analyses were carried out in order to better define the model response regarding the crop estimates. We also used some available information in the literature to complement the parametrization of the phenology and growth. The parametrization process was considered complete when an equilibrium between observed and simulated variables was attained.

The soil parametrization was performed by creating a soil file containing hydrophysical (Table 2) and chemical (Table 3) soil properties in each of the referred sites. The soil files consist of several submodules that include all the inputs necessary to specify the water balance and uptake of nutrients, which in turn were setup in the parametrization. Some soil chemical properties such as starting mineral $\mathrm{N}$ pools $\left(\mathrm{NH}_{4}\right.$ and $\left.\mathrm{NO}_{3}\right)$, organic carbon (OC), biomass fraction (FBIOM) and inert OC fraction (FINERT), were used according to Probert et al. (1998) due to the lack of experimental data (Table 3). The soil surface organic matter residues were modified aiming at more precise estimates of the soil water dynamics. This modification was necessary to adjust the initial surface residue (residue_wt), whose value was suggested by Probert et al. (1998) of $5000 \mathrm{~kg} \mathrm{ha}^{-1}$. However, this value was not in agreement with the soil water 
measurements. For this reason, we reduced the initial surface residue to $1000 \mathrm{~kg} \mathrm{ha}^{-1}$ for both sites, which allowed for better estimates. In addition, the depth of the radicular system in the Arapiraca simulation had to be increased (from 60 to $75 \mathrm{~cm}$ ) for the fourth sowing date to obtain better predictions of LAI and biomass (see results).

Some modifications had to be made to achieve a better fit of the predicted LAl to the observations (Table 4). Firstly, the $x_{\text {_lai }}$ parameter, which represents the variation of LAI, was changed to fit into experimental LAI variation that achieved a maximum value of 5.6. This, in turn, exceeded the upper limit previously considered in the model $(\mathrm{LAI}=4.0)$. Second, the leaf_no_dead_slope parameter was changed to represent the decay in the LAI curve according to Archontoulis et al. (2014). Finally, the lai_sen_light parameter, which indicates when the induced senescence occurs, was modified due to the same reason the parameter "x lai" was changed.

\section{Nutritional management configuration}

The nutritional management was programmed using the function "fertilizer apply amount", which in addition to indicating the fertilizer amount also specifies the constituents and application depth. The fertilizer application was shaped in order to represent the experimental applications, which in turn was performed by foundation fertilization and topdressing. The foundation fertilization in the Arapiraca site was $40 \mathrm{~kg} \mathrm{ha}^{-1}$ of nitrogen (N), $60 \mathrm{~kg} \mathrm{ha}^{-1}$ of phosphorus pentoxide $\left(\mathrm{P}_{2} \mathrm{O}_{5}\right), 50 \mathrm{~kg} \mathrm{ha}^{-1}$ of potassium oxide $\left(\mathrm{K}_{2} \mathrm{O}\right)$ and $2 \mathrm{~kg} \mathrm{ha}^{-1}$ of Zinc ( $\left.\mathrm{Zn}\right)$ and topdressing utilized $100 \mathrm{~kg} \mathrm{ha}^{-1}$ of $\mathrm{N}$. In the Rio Largo experiment, the following was used: $10 \mathrm{~kg} \mathrm{ha}^{-1}$ of $\mathrm{N}, 60 \mathrm{Kg} \mathrm{ha}^{-1}$ of $\mathrm{P}$ and $45 \mathrm{~kg} \mathrm{ha}^{-1}$ of $\mathrm{K}$ (foundation fertilization) and $60 \mathrm{~kg} \mathrm{ha}^{-1}$ of $\mathrm{N}$ (topdressing) whose sources were ammonium sulfate $\left(\left(\mathrm{NH}_{4}\right)_{2} \mathrm{SO}_{4}\right)$, single superphosphate (SSP) and potassium chloride (KCl). However, the model accepts only nutritional sources based on nitrogen $(\mathrm{N})$ and phosphorus $(\mathrm{P})$ and for this reason, fertilization using potassium as a source of nutrients was not considered in programming the nutritional management. Foundation fertilization was programmed at the beginning of the simulation (sowing date) and there were two types of topdressing corresponding to the V4 (fourth fully expanded leaf at 15 DAS) and V8 (eighth fully expanded leaf at 30 DAS) phonological stages, according to the experimental practices. The $\mathrm{N}$ source used in the model was ammonia nitrate $\left(\mathrm{NH}_{4} \mathrm{NO}_{3}\right)$ which contains about $34 \%$ of $\mathrm{N}$ (Malavolta et al., 2002). Since the APSIM does not accept the ammonia sulphate as a source of $\mathrm{N}$, the $\mathrm{NH}_{4} \mathrm{NO}_{3}$ amount inserted into the model had to be adjusted by proportionality in order to correspond to the $\mathrm{N}$ applied experimentally. After this adjustment in the $\mathrm{N}$, the fertilizer amount programmed for the Arapiraca simulation was $117.6 \mathrm{~kg} \mathrm{ha}^{-1}$ of $\mathrm{NH}_{4} \mathrm{NO}_{3}$ in the foundation fertilization and $206 \mathrm{~kg} \mathrm{ha}^{-1}$ of $\mathrm{NH}_{4} \mathrm{NO}_{3}$ for each topdressing programmed. For Rio Largo, it was programmed as $29.4 \mathrm{~kg} \mathrm{ha}^{-1}$ of $\mathrm{NH}_{4} \mathrm{NO}_{3}$ in the foundation fertilization and $88.2 \mathrm{~kg} \mathrm{ha}^{-1}$ of $\mathrm{NH}_{4} \mathrm{NO}_{3}$ for each topdressing.

\section{Crop variety implementation}

The APSIM platform does not include the maize variety (AL Bandeirante) used in the field experiment, hence the need to implement it in the model. The required phonological parameters, based on the accumulated degree-day (ADD) regarding varieties such as: ADD between the beginning and the end of the juvenile stage (tt emerg to endjuv), between the flowering and maturity (tt_flower_to_maturity); the flag leaf appearance and flowering (tt_flag_to flower) and flowering to the beginning of the grain filling (tt_flower_to_start_grain); and ADD between maturity and harvest (tt_maturity_to_reap) were introduced into the maize.xml file. These phenological parameters are shown in Table 5

\section{Statistical analysis}

The performance of the APSIM model was quantitatively given by different statistical tests, such as i) model error ( \pm 20\%); and ii) Root mean Square Error (RMSE), indicating respectively the relative and absolute mean error, which both show a better fit when the indices approach zero; iii) determination coefficient $\left(R^{2}\right)$; iv) Willmott's index of agreement $(d)$ and $v$ ) modelling efficiency (EF), where these last three perform better when their values are high. These statistical variables are described in detail in Yang et al., (2014a).

\section{Conclusions}

From the model-observation comparisons, it can be concluded that the APSIM-Maize model satisfactorily predicted the LAI of the AL Bandeirante maize variety under well-drained soil conditions. The biomass production was satisfactorily predicted for Rio Largo. On the other hand, for Arapiraca, the model was able to attain a good performance only for the grain yield with an error less than $\pm 20 \%$ within the range considered acceptable. The soil water dynamic estimations showed good precision under well-drained soil. In the conditions under impaired drainage (Rio Largo's soil), the model did not properly predict the soil water dynamics. A better agreement was achieved after a drainage parameter adjustment, but despite this, the model was incapable of simulating SW accurately. Further adjustments in drainage parameters are still required in order to simulate the soil water dynamics and LAI variations more accurately. Finally, this study showed that the APSIM model is a very useful tool to help establish agricultural policies and optimize production systems in the region. In the present study, the model was evaluated for specific environmental conditions, and therefore these results should not be extrapolated to other conditions without the necessary adjustments.

\section{Acknowledgments}

The first author was supported by a scholarship from the Coordination for the Improvement of Higher Education Personnel (CAPES) and research projects were funded by a grant from the National Council for Scientific and Technological Development (CNPq). We would like to thank Gilson Moura Filho for providing soil data measurements to feed the model; Leandro Cerqueira for sharing information about the APSIM model; and the anonymous reviewers for their contributions to improve this manuscript.

\section{References}

Asseng S, Keating BA, Fillery, IRP, Gregory PJ, Bowden JW, Turner NC, Palta JA, Abrecht DG (1998) Peformance of the apsim-wheat model in Western Austrália. Field Crops Res. 57:163-179. 
Archontoulis SV, Miguez FE, Moore KJ (2014) Evaluating apsim maize, soil water, soil nitrogen, manure, and soil temperature modules in the Midwestern United States. Agron J. 106:10251040.

Bassu S, Brisson N, Durand JL, Boote K, Lizaso J, Jones JW, Rosenzweig C, Ruane AC, Adam M, Baron C, Basso B, Biernath C, Boogaard H, Conijn S, Corbeels M, Deryng D, De Sanctis G, Gayler S, Grassini P, Hatfield J, Hoek S, Izaurralde C, Jongschaap R, Kemanian AR, Kersebaum KC, Kim SH, Kumar NS, Makowski D, Müller C, Nendel C, Priesack E, Pravia MV, Sau F, Shcherbak I, Tao F, Teixeira E, Timlin D, Waha K (2014) How do various maize crop models vary in their responses to climate change factors? Glob Change Biol. 20:2301-2320.

Carberry PS, Muchow RC, Hammer GL (1993) Modelling genotypic and environmental control of leaf area dynamics in grain sorghum. II. Individual leaf level. Field Crops Res. 33:311-328.

CONAB - Companhia nacional de abastecimento - Levantamento de safra.

Available

in<http://www.conab.gov.br/conteudos.php?a=1253\&> Accessed in: June of 2018.

de Wit CT (1965) Photosynthesis of leaf canopies, Report 663, Center for Agric. Publ. and Doc., Wageningen, The Netherlands.

FAO - Food and Agriculture Organization of the United Nations faostat online database. Available in <http://faostat3.fao.org/> Accessed in: June of 2018

Ferreira Junior RA, Souza JL, Teodoro I, Lyra GB, de Souza RC, Araújo Neto RA, (2014) Eficiência do uso da radiação em cultivos de milho em Alagoas. Rev Bras Eng Agric Ambent. 18:322-328.

Holzworth D, Huth N, deVoil P, Zurcher E, Herrman N, McClean G, Chenuc K, van Oosterom EK, Snow V, Murphy C, Moore AD, Brown $H$, Whish JPM, Verralla S, Fainges J, Bell LW, Peake AS, Poulton PL, Hochman Z, Thorburn PJ, Gaydon DS, Dalgliesh NP, Rodriguez D, Cox H, Chapman S, Doherty A, Teixeira E, Sharp J, Cichota R, Vogeler I, Li SY, Wang E, Hammer GL, Robertson MJ, Dimes JP, Whitbrea, AW, Hunt, J, van Rees $\mathrm{H}$, McClelland T, Carberry PS, Hargreaves JNG, MacLeod N, McDonald C, Harsdorf J, Wedgwood S, Keating BA (2014) Apsim - evolution towards a new generation of agricultural systems simulation. Environ Modell Softw. 65:327-350.

Keating BA, Carberry PS, Hammer GL, Probert ME, Robertson MJ, Holzworth D, Huth NI, Hargreaves JNG, Meinke H, Hochman Z, Mclean G, Verbug K, Snow V, Dimes JP, Silburn M, Wang E, Brown E, Bristow KL, Asseng S, Chapman S, Mccown RL, Freebairn DM, Smith CJ (2003) An overview of apsim, a model designed for farming systems simulation. Eur J Agron. 18:267-288.

Kiniry JR, Williams JR, Vanderlip RL, Atwood JD, Reicosky DC, Mulliken J, Cox WJ, Mascagni HJ, Hollinger SE, Wiebold WJ (1997) Evaluation of two maize models for nine US locations. Agron J. 89:421-426.

Koizumi T (2015) Biofuels and food security. Renew Sust Energ Rev. 52:829-841.

Lyra GB, Souza JL, Teodoro I, Lyra GB, Moura Filho G, Ferreira Junior RA (2010) Conteúdo de água no solo em cultivo de milho sem e com cobertura morta na entrelinha na região de Arapiraca-AL. Irriga. 15:173-183.

Loague K, Green RE (1991) Statistical and graphical methods for evaluating solute transport models: Overview and application. In: P.J Wierenga (Guest Editor), Validation of Flow and Transport Models for the Unsaturated Zone. J Contam Hydrol. 7:51-73.

Malavolta E, Pimentel-Gomes F, Alcarde JC (2002) Adubos e adubações. Nobel, São Paulo.

Medeiros RP (2009) Components of water balance and solar radiation related to development of corn in four planting dates in the agreste region of Alagoas (master's thesis). Federal University of Alagoas, Brazil. Available in <http://www.repositorio.ufal.br/handle/riufal/238> Accessed in: June of 2018.

Meinke H, Hammer LG, Van Keulen H, Rabbinge R, Keating BA (1997) Improving wheat simulation capabilities in Australia from a cropping system perspective: water and nitrogen effects on spring wheat in a semi-arid environment. Eur J Agron. 7:75-88.

Mohanty M, Probert ME, Reddy KS, Dalal RC, Mishra AK, Rao AS, Singh M, Menzies NW (2012) Simulating soybean-wheat cropping system: APSIM model parametrization and validation. Agric Ecosyt Environ. 152:68- 78.

Muchow RC, Sinclair TR, Bennett JM (1990) Temperature and solar radiation effects on potential maize yield across locations. Agron J. 82:338-343.

Ojeda JJ, Pembleton KG, Islame MR, Agnusdei MG, Garcia SC (2016) Evaluation of the agricultural production systems simulator simulating lucerne and annual ryegrass dry matter yield in the Argentine Pampas and south-eastern Australia. Agric Sys 143:6175.

Probert ME, Dimes JP. Keating BA, Dalal RC,Strong, WM (1998) Apsim's water and nitrogen modules and simulation of the dynamics of water and nitrogen in fallow systems. Agric Sys. 56(1):1-28. Roxburgh CW, Rodriguez D (2016) Ex-ante analysis of opportunities for the sustainable intensification of maize production in Mozambique. Agric Sys. 142:9-22.

Roberts MJ, Braun NO, Sinclair TR, Lobell DB, Schlenker W (2017) Comparing and combining process-based crop models and statistical models with some implications for climate change. Environ Res Lett. 12:095010.

Sarmento, PLVS (2015) Ecofisiologia do milho sob diferentes épocas de semeadura e densidades de plantio (master's thesis). Federal University of Alagoas, Brazil.

Silva, MBP (2013) Desenvolvimento de milho em função de variáveis agroambientais em diferentes épocas de semeio (undergraduate thesis). Federal University of Alagoas, Brazil.

Singh B, Eberback, PL, Humphreys, E (2014) Simulation of the evaporation of soil water beneath a wheat crop. Agric Water Manag. 135:19-26.

Singer JW, Meek DW, Sauer TJ, Prueger JH, Hatfield, JL (2011) Variability of light interception and radiation use efficiency in maize and soybean. Field Crops Res. 121:147-152.

Song Y, Birch C, Qu S, Dohert A, Hanan J (2010) Analysis and modelling of the effects of water stress on maize growth and yield in dryland conditions. Plant Prod Sci, 13:2-199-208.

Souza JL, Moura Filho, G, Lyra RFF, Teodoro I, Santos EA, Silva JL, Silva PRT, Cardim AH, Amorim EC (2004) Análise da precipitação pluvial e temperatura do ar na região do tabuleiro costeiro de Maceió, AL. Período 1972 - 2001. Rev Bras Agrometorol. 12:131141.

Willmott CJ (1981) On the validation of models. Physical Geogr. 2:184-194.

Yang JM, Yang JY, Liu S, Hoogenboom G (2014a) An evaluation of the statistical methods for testing the performance of crop models with observed data. Agric Sys. 127:81-89.

Yang Y, Yang Y, Han S, Macadam I, Liu DL (2014b) Prediction of cotton yield and water demand under climate charge and future adaptation measures. Agric Water Manag. 144:42-53.

Zeleke KT, Luckett DJ, Cowley RB (2014) The influence of soil water conditions on canola yields and productions in Southern Australia. Agric Water Manag. 144:20-32. 